\title{
GROWTH AND NUTRIENT ACCUMULATION AND EXPORT IN A SHORT-DAY ONION $^{1}$
}

\author{
CAROLINA CINTO DE MORAES ${ }^{2}$, HUMBERTO SAMPAIO DE ARAÚJO ${ }^{3}$, THIAGO LEANDRO FACTOR ${ }^{4}$, ALEX \\ HUMBERTO CALORI ${ }^{2}$, LUIS FELIPE VILLANI PURQUERIO ${ }^{2}$
}

\begin{abstract}
New hybrid onions that are more productive are currently being cultivated. Information on growth and nutrient accumulation must thus be updated to assist in the refinement of existing recommendations, enabling the better exploitation of the productive potential of these new genotypes. We determined the growth of plants and the accumulation and export of nutrients of the short-day onion 'Soberana' established by direct seeding. The experimental design was a randomized block with four replicates and the treatments were evaluation times. Leaf number, tissue dry weight, nutrient accumulation, and the maximum daily rate of accumulation were evaluated throughout the growing cycle. The order of nutrient accumulation was $\left(\right.$ g plant $\left.^{-1}\right) \mathrm{K}(0.72)>\mathrm{Ca}(0.38)>\mathrm{N}(0.32)>\mathrm{S}(0.14)>\mathrm{P}(0.08)>\mathrm{Mg}(0.06)$ and $\left(\mathrm{mg} \mathrm{plant}^{-1}\right) \mathrm{Fe}(2.26)>$ $\mathrm{Mn}(1.43)>\mathrm{Cu}(0.93)>\mathrm{Zn}(0.91)>\mathrm{B}(0.85)$. Macronutrient demand was highest between 61 and 148 days after sowing (DAS), and micronutrient demand was highest between 70 and 148 DAS.
\end{abstract}

Keywords: Allium cepa L.. Horticulture. Plant Nutrition. Fertilizing. Sustainability.

\section{CRESCIMENTO, ACÚMULO E EXPORTAÇÃO DE NUTRIENTES DE CEBOLA DE DIAS CURTOS}

RESUMO - Novos híbridos de cebola mais produtivos estão sendo cultivados atualmente. Assim, informações sobre o crescimento e absorção de nutrientes devem ser atualizadas para auxiliar no refinamento das recomendações existentes, possibilitando melhor explorar o potencial produtivo desses novos genótipos. Objetivou-se com o trabalho determinar o crescimento, acúmulo e exportação de nutrientes do híbrido de cebola Soberana no sistema de semeadura direta. O delineamento experimental foi o de blocos casualizados, com quatro repetições, onde os tratamentos foram épocas de avaliação. Avaliou-se o número de folhas, massa seca, acúmulo de nutrientes e a taxa máxima de acumulo diário. A sequência de acúmulo de nutrientes foi ( $\mathrm{g}$ planta $\left.^{-1}\right): \mathrm{K}(0,72)>\mathrm{Ca}(0,38)>\mathrm{N}(0,32)>\mathrm{S}(0,14)>\mathrm{P}(0,08)>\mathrm{Mg}(0,06)$ e $\left(\mathrm{mg} \mathrm{planta}^{-1}\right) \mathrm{Fe}(2,26)>\mathrm{Mn}$ $(1,43)>\mathrm{Cu}(0,93)>\mathrm{Zn}(0,91)>\mathrm{B}(0,85)$. A exigência máxima dos macronutrientes ocorreu entre 61 e 148 dias após a semeadura (DAS) e dos micronutrientes entre 70 e 148 DAS.

Palavras-chave: Allium cepa L.. Horticultura. Nutrição de plantas. Adubação. Sustentabilidade.

\footnotetext{
${ }^{*}$ Corresponding author

${ }^{1}$ Received for publication in 02/08/2017; accepted in 01/22/2018

Paper extracted from the masters dissertation of the first author.

${ }^{2}$ Horticulture Center, Instituto Agronômico, Campinas, SP, Brazil; carolcmoraes@hotmail.com - ORCID: 0000-0002-5011-5282, ahcalori@gmail.com - ORCID: 0000-0002-0943-3609, felipe@iac.sp.gov.br- ORCID: 0000-0002-2962-4517.

${ }^{3}$ Regional Extreme West Pole, Agência Paulista de Tecnologia dos Agronegócios, Andradina, SP, Brazil; humbertosaraujo@yahoo.com.br - ORCID: 0000-0001-6651-2816.

${ }^{4}$ Regional Action Center, Instituto Agronômico, Mococa, SP, Brazil; factor@apta.sp.gov.br - ORCID: 0000-0003-0234-4256.
} 


\section{INTRODUCTION}

The onion is among the most economically important vegetables in Brazil. Approximately 57000 ha were cultivated in 2015, producing $1461000 \mathrm{t}$ at an average yield of $26 \mathrm{t} \mathrm{ha}^{-1}$ (IBGE, 2016).

The use of hybrids and new cultivation technologies can increase onion yield three-fold above the national average. These new hybrids have better bulb uniformity than open-pollinated cultivars and can thus tolerate high planting densities and are more productive (COSTA et al., 2002). They are also resistant to pests and diseases, adapted to different climatic conditions, and better able to use the available inputs. The plants are consequently better adapted for mass production, which affects their nutritional needs (PURQUERIO; SANTOS; FACTOR, 2016). Adequate plant nutrition can directly improve bulb health, quality and yield (KURTZ; ERNANI, 2010). Characterizing plant growth and nutrient uptake throughout the growing cycle is thus essential for crop planning to maximize productive potential (VIDIGAL et al., 2009; PURQUERIO, 2010).

Monitoring the uptake of nutrients can identify the periods of higher nutritional requirement and dry-matter production and provide reliable information on the most convenient times of fertilizer application, avoiding the possible deficiency or over-consumption of some nutrients (HAAG; MINAMI, 1988; FURLANI; PURQUERIO, 2010). Information about nutrient accumulation and export by onions under various cultivation conditions and for various genotypes should thus be used as references for defining the management of soil fertility.

Some information is available about the accumulation of nutrients by hybrids and open-pollinated onion cultivars in Brazil, from studies with hybrids Optima (PÔRTO et al., 2006) and Superex (PÔRTO et al., 2007); the cultivars Alfa Tropical (VIDIGAL; MOREIRA; PEREIRA, 2010), IPA 11, and Texas Grano 502 (AGUIAR NETO et al., 2014); and recently the hybrid Aquarius (MORAES et al., 2016) and the cultivar Bola Precoce (KURTZ et al., 2016). The results of these studies, however, indicated large differences in the quantities and proportions of nutrients accumulated by the plants due to the genotypic variations of each cultivar, environmental conditions, and yield increase (FERNANDES; SORATTO; SILVA, 2011). Constantly updating nutrient-uptake studies of new genotypes on the market throughout the growing cycle is therefore essential (FACTOR et al., 2018). This information is essential for onion crops to assist in the amendment of existing fertilizer recommendations. The aim of this study was thus to monitor plant growth and the accumulation and export of nutrients for 'Soberana' onions.

\section{MATERIAL AND METHODS}

The experiment was carried out near the city of Santo Antônio de Posse, São Paulo (SP) $\left(22^{\circ} 18^{\prime} 00^{\prime \prime} \mathrm{S}, 47^{\circ} 00^{\prime} 00^{\prime \prime} \mathrm{W}\right.$; $585 \mathrm{~m}$ a.s.l.) from 02 April to 27 August 2014. The chemical properties of the soil $(0-0.2 \mathrm{~m})$ were: $\mathrm{pH} 5.1,35 \mathrm{~g}$ organic matter $\mathrm{dm}^{-3}, 60.0 \mathrm{mg} \mathrm{P} \mathrm{dm}{ }^{-3}, 4.5 \mathrm{mmol}_{\mathrm{c}} \mathrm{K} \mathrm{dm}^{-3}, 40 \mathrm{mmol}_{\mathrm{c}}$ $\mathrm{Ca} \mathrm{dm}{ }^{-3}, 20 \mathrm{mmol}_{\mathrm{c}} \mathrm{Mg} \mathrm{dm}^{-3}, 31 \mathrm{mmol}_{\mathrm{c}} \mathrm{H}+\mathrm{Al} \mathrm{dm}{ }^{-3}$, $0.4 \mathrm{mmol}_{\mathrm{c}} \mathrm{Na} \mathrm{dm}^{-3}, 1.41 \mathrm{mg} \mathrm{B} \mathrm{dm}{ }^{-3}, 4.9 \mathrm{mg} \mathrm{Cu} \mathrm{dm}^{-3}$, $15 \mathrm{mg} \mathrm{Fe} \mathrm{dm}{ }^{-3}, 4.1 \mathrm{mg} \mathrm{Mn} \mathrm{dm}{ }^{-3}, 5.9 \mathrm{mg} \mathrm{Zn} \mathrm{dm}^{-3}$, and a cation-exchange capacity of $95.5 \mathrm{mmol}_{\mathrm{c}} \mathrm{dm}^{-3}$. The soil contained $20 \%$ coarse sand, $18 \%$ fine sand, $9 \%$ silt, and $53 \%$ clay.

The maximum, mean, and minimum air temperatures during the experimental period were 27.4, 18.4, and $10.6{ }^{\circ} \mathrm{C}$, respectively (Figure $1 \mathrm{~A}$ ). Total rainfall was $270.4 \mathrm{~mm}$ (Figure 1B).
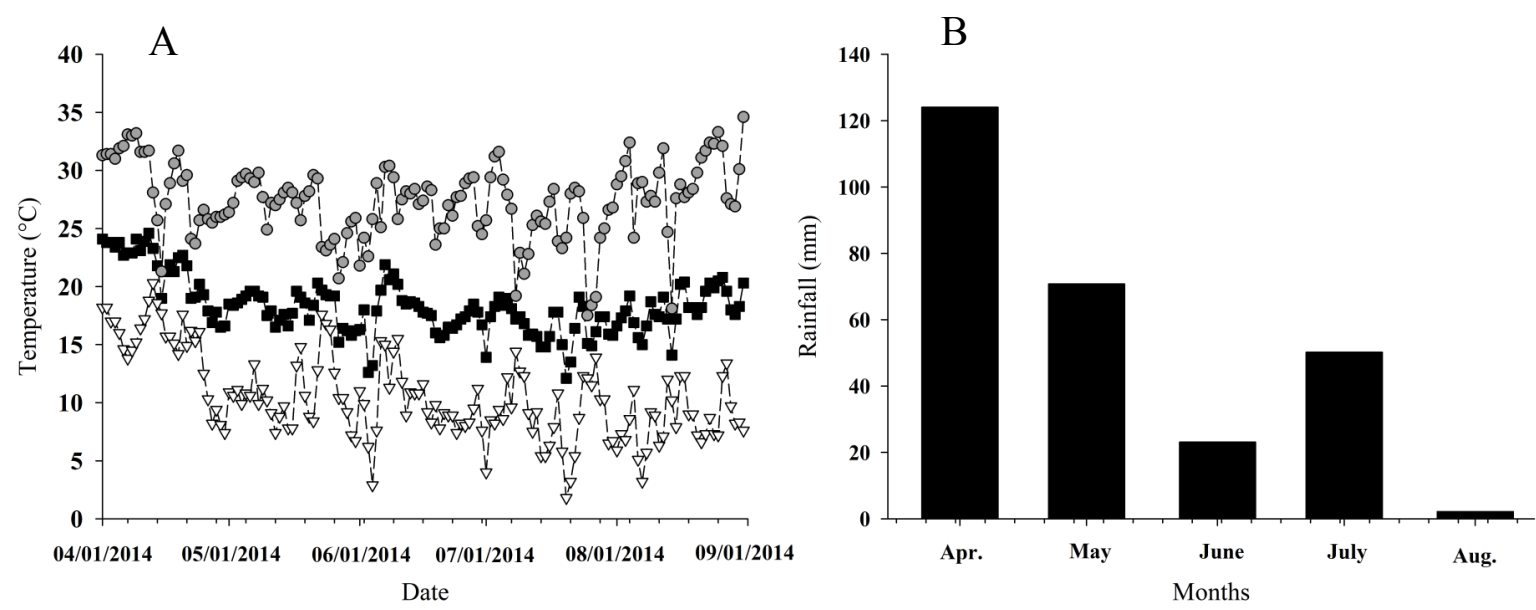

Figure 1. Maximum, mean, and minimum air temperatures (A) and rainfall (B) from April to August 2014. 
The experimental design was randomized blocks with four replicates. The treatments were evaluation periods $36,50,64,78,92,106,120,134$, and 148 days after sowing (DAS). Each block consisted of a bed $30 \mathrm{~m}$ long and $1.1 \mathrm{~m}$ wide. Two additional beds were prepared as borders along the length of the plots. The total experimental area was $270 \mathrm{~m}^{2}$.

Soil preparation consisted of plowing, harrowing, and the preparation of beds. Basal fertilization consisted of $35.0 \mathrm{~kg} \mathrm{~N} \mathrm{ha}^{-1}$,

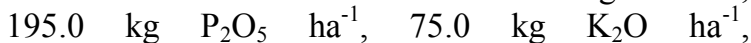
$150.0 \mathrm{~kg} \mathrm{~S} \mathrm{ha}{ }^{-1}, 1.3 \mathrm{~kg} \mathrm{~B} \mathrm{ha}{ }^{-1}$, and $4.0 \mathrm{~kg} \mathrm{Zn} \mathrm{ha}^{-1}$. Side dressings consisted of $40.0 \mathrm{~kg} \mathrm{~N} \mathrm{ha}{ }^{-1}$ and $35.0 \mathrm{~kg} \mathrm{~S} \mathrm{ha}^{-1}$ split at 15 and $80 \mathrm{DAS}$; $140.0 \mathrm{~kg} \mathrm{~K}_{2} \mathrm{O} \mathrm{ha}^{-1}$ split at 80,98 , and $120 \mathrm{DAS}$; and $33 \mathrm{~kg} \mathrm{Ca} \mathrm{ha}^{-1}$ at 80 DAS. Applications were based on the soil analysis and the recommendations for SP (TRANI; RAIJ, 1997), with adaptations for the hybrid studied. The fertilizers used were calcium nitrate $(14 \% \mathrm{~N}$ and $18 \% \mathrm{Ca})$, ammonium sulfate $(20 \% \mathrm{~N}$ and $23 \% \mathrm{~S})$, single superphosphate $(18 \%$ $\mathrm{P}_{2} \mathrm{O}_{5}$ and $\left.10 \% \mathrm{~S}\right)$, potassium chloride $\left(58 \% \mathrm{~K}_{2} \mathrm{O}\right)$, potassium sulfate $\left(48 \% \mathrm{~K}_{2} \mathrm{O}\right.$ and $\left.16 \% \mathrm{~S}\right)$, boric acid $(17 \% \mathrm{~B})$, and zinc sulfate $(20 \% \mathrm{Zn}$ and $9 \% \mathrm{~S})$.

We used the hybrid onion Soberana (Agristar), characterized by round and yellow bulbs approximately $60.0 \mathrm{~mm}$ in diameter and a medium weight of $165.0 \mathrm{~g}$. The onion is planted in March and April in SP and in April and May in southern Brazil (AGRISTAR, 2015). The onions were mechanically planted on 02 April 2014 in beds in four lines with row and plant spacings of 0.30 and $0.04 \mathrm{~m} \mathrm{(25}$ plants $\left.\mathrm{m}^{-1}\right)$, respectively. The plants were thinned 22 DAS to one plant every $0.08 \mathrm{~m}\left(12\right.$ plants $\mathrm{m}^{-1}$, 320000 plants $\left.\mathrm{ha}^{-1}\right)$. The plants were watered by drip irrigation with one line between onion rows and $20 \mathrm{~cm}$ between emitters. Phytosanitation was performed as needed.

Samples were collected at intervals of 14 days beginning on 07 May (36 DAS). The numbers of leaves and bulbs, root dry mass (DM), nutrient accumulation, and yield were evaluated. Diagnostic shoots were collected at 78 DAS for the analysis of tissue nutrient contents (TRANI; RAIJ, 1997).

We collected 200 and 80 plants from the two central lines of each plot in the first and second evaluations, respectively, 10 plants from the third to seventh evaluations, and four plants from the eighth and ninth evaluations. Six plants were left as a border for the subsequent collections. The last evaluation was at 148 DAS, when more than $60 \%$ of the plants were ready for harvesting (leaves clicked down).

The collected plants were washed with water and detergent and separated into leaves, bulbs, and roots, which were then dried in a forced-air circulation oven at $60{ }^{\circ} \mathrm{C}$ to a constant dry weight. The dry material was weighed and chemically analyzed to determine the nutrient $(\mathrm{N}, \mathrm{P}, \mathrm{K}, \mathrm{Ca}, \mathrm{Mg}$,
$\mathrm{S}, \mathrm{B}, \mathrm{Cu}, \mathrm{Fe}, \mathrm{Mn}$, and $\mathrm{Zn}$ ) contents of the tissues (leaves, bulbs, and roots) as described by Malavolta, Vitti and Oliveira (1997). The root system was collected in a soil volume of approximately $0.2 \times 0.2 \times 0.2 \mathrm{~m}$. Nutrient accumulation was calculated by multiplying the content of each nutrient in each tissue (leaves, bulbs, and roots) by the DM of each tissue. The total accumulation of each nutrient in the plant was determined by the sum of the accumulations in the tissues. The data for nutrient accumulation were analyzed using a non-linear three-parameter regression model defined by the best statistical fit ( $F$ test) and the coefficient of determination $\left(R^{2}\right)$. SigmaPlot 12.5 (Systat Software, USA) was used for the analyses.

Nutrient daily accumulation rates (NDARs) were obtained by the difference between adjusted accumulations for two consecutive days. The inflection points of the adjusted curves corresponded to the times of maximum NDARs. The periods of highest accumulation of dry mass and nutrients were determined by the minimum and maximum curve points in sigmoidal models calculated using the method described by Venegas, Harris and Simon (1998). The export of nutrients was calculated by multiplying the nutrient accumulations in the bulb at 148 DAS by the total number of plants ha ${ }^{-1}(320000)$

\section{RESULTS AND DISCUSSION}

The number of leaves increased from the beginning of the growing cycle until harvest (12 leaves) at 148 DAS (Figure 2). Number of leaves is a phenological characteristic that can be used instead of DAS to monitor plant development over time. It can thus be used to plan nutrient distribution during growing seasons and in regions where environmental conditions affect the duration of the growing cycle (MORAES et al., 2016).

The accumulation of DM (leaves, bulbs, and roots) by the plants was low until 64 DAS, representing only $7 \%\left(2.4 \mathrm{~g} \mathrm{plant}^{-1}\right)$ of the total of $36.8 \mathrm{~g} \mathrm{plant}^{-1}$ at 148 DAS (Figure 2). DM accumulation was highest from 81 to 148 DAS, at $85 \%$ ( 31.4 g plant $\left.^{-1}\right)$ of the estimated total. Plant DM increased significantly when 'Soberana' had eight leaves, so we inferred that the plants required a vegetative canopy with $72 \%$ of the leaves present at the end of the growing cycle to initiate the largest increase in DM. The estimated foliar DM accumulation was highest $\left(17.0 \mathrm{~g} \mathrm{plant}^{-1}\right)$ at 148 DAS. Accumulation was only $12 \%\left(2.1 \mathrm{~g} \mathrm{plant}^{-1}\right)$ of the maximum estimated by 73 DAS. DM accumulation then intensified until 117 DAS, totaling $76 \%$ (15.1 $\left.\mathrm{g} \mathrm{plant}^{-1}\right)$. The accumulation then slowed and tended to stabilize. Similar results of slow foliar DM accumulation until 70 DAS were reported for 'Optima' and 'Superex', with subsequent acceleration until 110 DAS and then 
stabilization (PÔRTO et al., 2006, 2007).

Foliar DM accumulation decreased during the accumulation of bulb DM. Bulb DM accumulation accelerated from 106 DAS until harvest (148 DAS). Eighty-four percent $\left(17.8 \mathrm{~g} \mathrm{plant}^{-1}\right)$ of the highest estimated accumulation (21.2 $\left.\mathrm{g} \mathrm{plant}^{-1}\right)$ occurred during this period (Figure 2). The decrease in foliar accumulation can be justified by onion leaves senesce due to bulb growth, which is attributed to the translocation of photoassimilates to the bulb during maturation (BREWSTER, 1994). Roots accumulated nearly all of their DM by 120 DAS. The estimated $\mathrm{DM}$ at harvest was $0.4 \mathrm{~g}_{\text {plant }}{ }^{-1}$. Root DM, however, represented only $1 \%$ of the total plant DM.

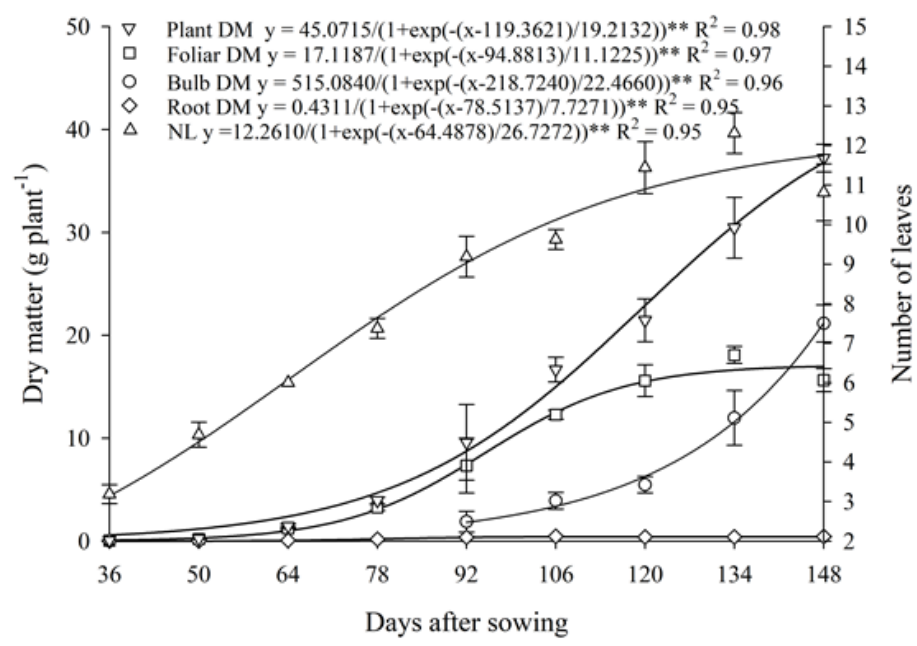

Figure 2. Accumulation of dry mass (DM) and number of leaves (NL) for the 'Soberana' onion during the growing cycle. The error bars represent mean standard errors.

The plant tissues collected at 78 DAS contained $27.4 \quad \mathrm{~g} \quad \mathrm{~N} \quad \mathrm{~kg}^{-1}, \quad 6.8 \quad \mathrm{~g} \quad \mathrm{~S} \quad \mathrm{~kg}^{-1}$, $18.8 \mathrm{mg} \mathrm{Cu} \mathrm{kg}^{-1}, 71.5 \mathrm{mg} \mathrm{Fe} \mathrm{kg}^{-1}$, and $48.9 \mathrm{mg} \mathrm{Mn} \mathrm{kg}^{-1}$, within the ranges recommended by Trani and Raij (1997) of 25-35 $\mathrm{g} \mathrm{N} \mathrm{kg}^{-1}, 5-8 \mathrm{~g} \mathrm{~S} \mathrm{~kg}^{-1}$, 10-30 mg $\mathrm{Cu} \mathrm{kg}{ }^{-1}, 60-300 \mathrm{mg} \mathrm{Fe} \mathrm{kg}{ }^{-1}$, and 50-200 mg Mn kg-1. P content (4.1 $\mathrm{g} \mathrm{kg}^{-1}$ ) was slightly higher than the recommended range (2-4 $\left.\mathrm{g} \mathrm{P} \mathrm{kg}^{-1}\right)$, and the contents of $\mathrm{K}\left(28.9 \mathrm{~g} \mathrm{~kg}^{-1}\right)$, $\mathrm{Ca}\left(9.9 \mathrm{~g} \mathrm{~kg}^{-1}\right), \mathrm{Mg}\left(1.7 \mathrm{~g} \mathrm{~kg}^{-1}\right), \mathrm{B}\left(17.3 \mathrm{mg} \mathrm{kg}^{-1}\right)$, and $\mathrm{Zn}\left(27.5 \mathrm{mg} \mathrm{kg}^{-1}\right)$ were slightly lower than the recommended ranges of $30-50 \mathrm{~g} \mathrm{~K} \mathrm{~kg}^{-1}$, 15-30 $\mathrm{g} \mathrm{Ca} \mathrm{kg}^{-1}, 3-5 \mathrm{~g} \mathrm{Mg} \mathrm{kg}^{-1}, 30-50 \mathrm{mg} \mathrm{B} \mathrm{kg}^{-1}$, and 30-100 mg Zn kg-1. Nutrient contents, however, are inherent to each genotype, sampling time, and position of the collected leaves (TRANI; RAIJ, 1997).

$\mathrm{N}$ accumulation by 'Soberana' was highest (0.32 $\left.\mathrm{g} \mathrm{plant}^{-1}\right)$ at $148 \mathrm{DAS}$. The period of highest accumulation from 61 to 135 DAS corresponded to $81 \%$ of the total $\left(0.26 \mathrm{~g} \mathrm{plant}^{-1}\right)$ (Figure $\left.3 \mathrm{~A}\right)$. This period comprised the intensification of foliar (73-117 DAS) and bulb (after 106 DAS) DM accumulation. The plants at this stage had a greater demand for nutrients, probably due to the increase in the metabolic activity associated with cell division for forming new tissues (BREWSTER, 1994).
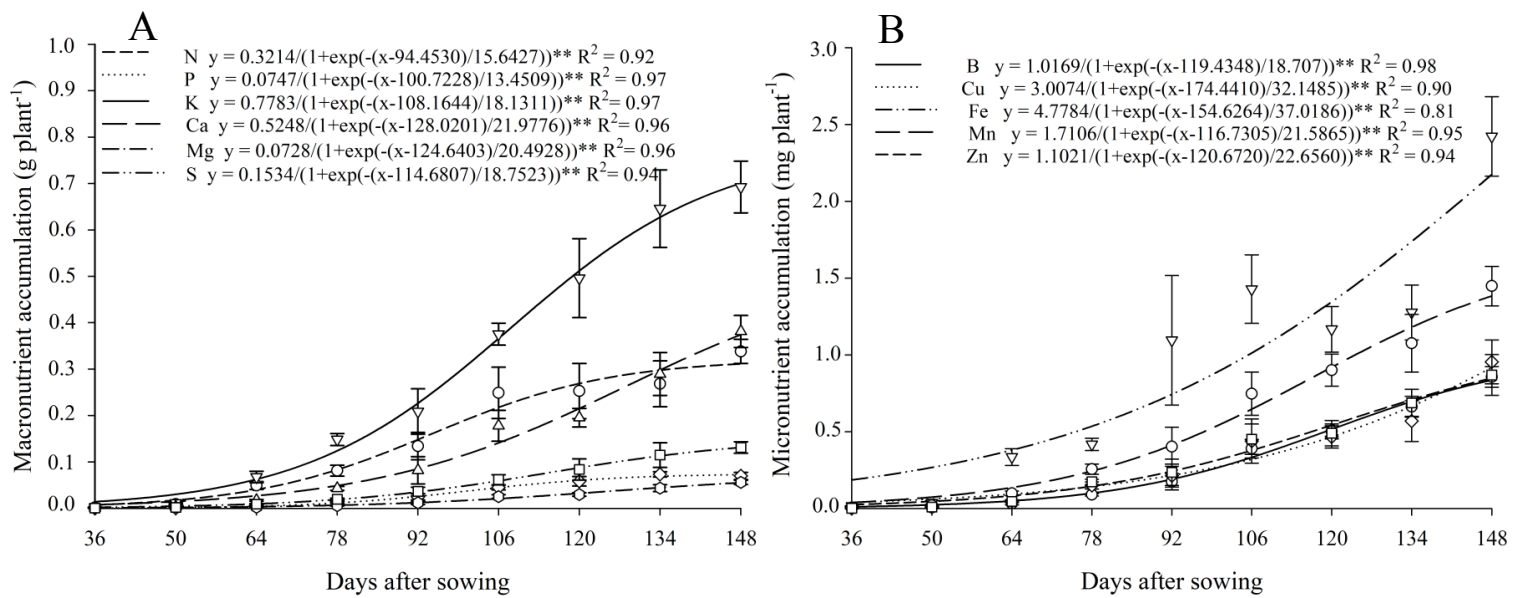

Figure 3. Accumulation of macronutrients (A) and micronutrients (B) for the 'Soberana' onion during the growing cycle. The error bars represent mean standard errors. 
The estimated $\mathrm{P}$ accumulation was highest $\left(0.08\right.$ g plant $\left.^{-1}\right)$ at 148 DAS. The plants accumulated $79 \%\left(0.06\right.$ g plant $\left.^{-1}\right)$ of the total from 72 to 129 DAS, the period of the highest demand (Figure 3A). P plays a key role in cell division, sexual reproduction, and plant metabolism, so it is essential for the growth of roots and shoots (THOMAZELLI et al., 2000).

$\mathrm{K}$ accumulation by 148 DAS $\left(0.72 \mathrm{~g} \mathrm{plant}^{-1}\right)$ was the highest of all nutrients. The period of highest requirement $\left(0.61 \mathrm{~g} \mathrm{plant}^{-1}\right)$ was from 70 to 144 DAS, equivalent to $84 \%$ of the total (Figure $3 \mathrm{~A}$ ). $\mathrm{K}$ has also been reported to be the most accumulated nutrient for the short-day onions 'Optima' (0.27 g plant $\left.{ }^{-1}\right)$, 'Superex' (0.29 g plant $\left.^{-1}\right)$, 'IPA 11' $\left(0.42 \mathrm{~g}\right.$ plant $\left.^{-1}\right)$, and 'Texas Grano $502^{\prime}\left(0.79, \quad 0.80 \mathrm{~g} \mathrm{plant}^{-1}\right)$ and the long-day onion 'Alfa Tropical' (0.24 $\mathrm{g} \mathrm{plant}^{-1}$ ) (PÔRTO et al., 2006; 2007; VIDIGAL; MOREIRA; PEREIRA, 2010; AGUIAR NETO et al., 2014; MORAES et al., 2016). The data for $K$ accumulation varies widely in the literature and the present study $(0.27$ to $0.80 \mathrm{~g}$ plant $\left.^{-1}\right)$ between genotypes and cultivation conditions, thus emphasizing the importance of studying DM and nutrient uptake.

The estimated $\mathrm{Ca}$ accumulation $\left(0.38 \mathrm{~g} \mathrm{plant}{ }^{-1}\right)$ was highest at 148 DAS. Its accumulation tended to intensify only after 84 DAS and remained constant until the end of the growing cycle, differing from $\mathrm{N}, \mathrm{P}$, and $\mathrm{K}$ (Figure 3A). The plants during this period accumulated $0.31 \mathrm{~g} \mathrm{Ca}$ plant $^{-1}$, equivalent to $83 \%$ of the highest estimated value. Ca accumulation also increases until the end of the cycle in the genotypes 'Alfa Tropical' (0.09 g plant $\left.{ }^{-1}\right)$ and Texas Grano 502 (0.24 g plant $^{-1}$ ) (VIDIGAL; MOREIRA; PEREIRA, 2010; AGUIAR NETO et al., 2014). Ca accumulation, however, tends to stabilize at the end of the growing cycle in 'Optima' (0.15 g plant $\left.{ }^{-1}\right)$, 'IPA 11' (0.53 $\left.\mathrm{g} \mathrm{plant}^{-1}\right)$, and 'Aquarius' (0.26 g plant $^{-1}$ ) (PÔRTO et al., 2006; AGUIAR NETO et al., 2014; MORAES et al., 2016).

The estimated $\mathrm{Mg}$ accumulation (0.06 $\left.\mathrm{g} \mathrm{plant}^{-1}\right)$ was highest at $148 \mathrm{DAS}$. The requirement for $\mathrm{Mg}$ was highest from 83 DAS until the end of the cycle and was equivalent to $84 \%$ $\left(0.05 \mathrm{~g} \mathrm{plant}^{-1}\right)$ of the highest estimate (Figure $\left.3 \mathrm{~A}\right)$. The maximum requirement began during the acceleration of foliar DM accumulation (73-117 DAS) and could be attributed to the participation of $\mathrm{Mg}$ in the structure of chlorophyll and the activation of enzymes in photosynthetic reactions (EPSTEIN; BLOOM, 2006).

$\mathrm{S}$ was the fourth most required macronutrient by the 'Soberana' hybrid. The highest estimated accumulation was $0.14 \mathrm{~g}$ plant $^{-1}$ (Figure 3A). $\mathrm{S}$ was also the fourth most accumulated nutrient for 'Superex' $\left(0.07 \mathrm{~g} \mathrm{plant}^{-1}\right)$, 'Alfa Tropical' $\left(0.07 \mathrm{~g} \quad\right.$ plant $\left.^{-1}\right), \quad$ and
'Aquarius' (0.17 g plant ${ }^{-1}$ ) (PÔRTO et al., 2007; VIDIGAL; MOREIRA; PEREIRA, 2010; MORAES et al., 2016). The maximum requirement began at 75 DAS and remained constant until harvest. S accumulation during this period was $0.12 \mathrm{~g} \mathrm{plant}^{-1}$, equivalent to $86 \%$ of the total. S not only increases onion yield, but also improves bulb quality, especially pungency and aroma (JAGGI; DIXIT, 1999; NASREEN; HAQ; HOSSAIN, 2003). The high demand for $\mathrm{S}$ until harvest is therefore likely due to its requirement by bulbs, as also reported by Pôrto et al. (2006, 2007) and Vidigal, Moreira and Pereira (2010).

The estimated accumulation of the micronutrient B was $0.85 \mathrm{mg}^{\text {plant }}{ }^{-1}$ at 148 DAS. The requirement began after 81 DAS and continued to increase until 148 DAS (Figure 3B). The plants accumulated $86 \%\left(0.73 \mathrm{mg}\right.$ plant $\left.^{-1}\right)$ of the total during this period (bulbification). The most important B functions are associated with cellular structure (EPSTEIN; BLOOM, 2006). We therefore inferred that $\mathrm{B}$ participated in the formation of the bulb peal, causing a demand for this nutrient until the end of the growing cycle.

$\mathrm{Cu}$ accumulation (0.93 $\mathrm{mg}$ plant $\left.^{-1}\right)$ was highest at 148 DAS. The period of its highest requirement ( $59 \%$ of the total, $0.55 \mathrm{mg} \mathrm{plant}^{-1}$ ) began at $112 \mathrm{DAS}$, later than those for the other micronutrients, and its accumulation continued to increase until harvest (Figure 3B). Cu accumulation increased throughout the growing cycle and was highest at the end, similar to 'Alfa Tropical' (VIDIGAL; MOREIRA; PEREIRA, 2010). Iron was the most accumulated micronutrient, as also reported for 'Alfa Tropical' (0.18 mg plant $\left.{ }^{-1}\right)$ (VIDIGAL; MOREIRA; PEREIRA, 2010), 'IPA 11' (7, 10 mg plant $\left.{ }^{-1}\right)$, 'Texas Grain 502' (3.41 mg plant ${ }^{-1}$ ) (AGUIAR NETO, 2013), and 'Aquarius' (2.17 mg plant $\left.{ }^{-1}\right)$ (MORAES et al., 2016). The estimated accumulation was highest $\left(2.26 \mathrm{mg}\right.$ plant $\left.^{-1}\right)$ at 148 DAS. The demand was highest between 53 and 141 DAS (Figure 3B), with an accumulation of $84 \%$ (1.89 $\left.\mathrm{mg} \mathrm{plant}^{-1}\right)$ of the highest value. The period of the highest $\mathrm{Fe}$ requirement was the longest of all micronutrients.

Mn accumulation was highest from 70 DAS until harvest, with an $86 \% \quad\left(1.23 \mathrm{mg}\right.$ plant $\left.{ }^{-1}\right)$ increase relative to the highest estimated value (1.43 mg plant $^{-1}$ ) (Figure 3B). Mn plays an important role in photosynthesis (EPSTEIN; BLOOM, 2006), so its maximum requirement begins shortly before the acceleration of foliar DM accumulation (73 to 117 DAS), as also observed for 'Aquarius', in which $84 \%$ of the accumulated Mn was in the leaves (MORAES et al., 2016).

The period of the highest $\mathrm{Zn}$ accumulation was between 71 and 148 DAS, with a constant increase, differing from those for 'Alfa Tropical', 'IPA 11', 'Texas Grano 502', and 'Aquarius' onions 
where accumulation stabilizes at the end of the growing cycle (VIDIGAL; MOREIRA; PEREIRA, 2010; AGUIAR NETO, 2013; MORAES et al., 2016). The accumulation represented $85 \%$ $\left(0.77 \mathrm{mg} \mathrm{plant}^{-1}\right)$ of the highest estimated value of $0.91 \mathrm{mg}^{-1}$ plant $^{-1}$ at 148 DAS (Figure 3B).

NDAR for 'Soberana' increased during the growing cycle to a maximum and then decreased later in the cycle, except for $\mathrm{Cu}$ (Figure 4A and B). The maximum NDARs for $\mathrm{N}, \mathrm{P}, \mathrm{K}, \mathrm{Ca}, \mathrm{Mg}$, and $\mathrm{S}$ were $0.005,0.001,0.011,0.006,0.001$, and $0.002 \mathrm{~g}$ plant $^{-1} \mathrm{~d}^{-1}$ at $98,101,107,129,125$, and $115 \mathrm{DAS}$, respectively (Figure 4A). The maximum NDARs for
$\mathrm{B}, \mathrm{Cu}, \mathrm{Fe}, \mathrm{Mn}$, and $\mathrm{Zn}$ were $0.014,0.020,0.028$, 0.020 , and $0.013 \mathrm{mg} \mathrm{plant}^{-1} \mathrm{~d}^{-1}$ at $120,148,97,114$, and 116 DAS, respectively, (Figure 4B).

Nutrients with daily accumulation rates can be distributed throughout the growing cycle so they can be available at times of high demand, thereby avoiding deficiencies and surpluses. The NDARs for the various nutrients were notably not highest at the same time, because the need for each nutrient varies with plant growth and tissue formation. Determining NDARs and identifying the periods of maximum requirement for each genotype is thus important for correct plant nutrition.
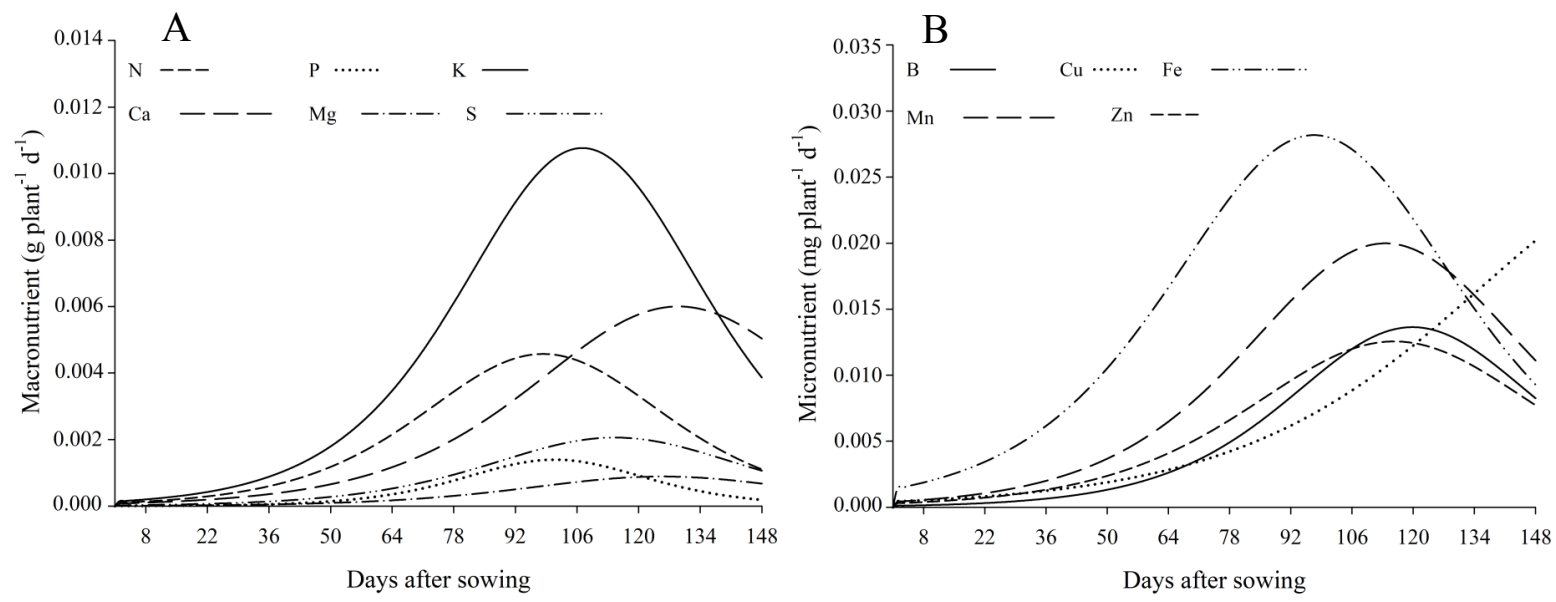

Figure 4. Daily accumulation rates of macronutrients (A) and micronutrients (B) for the 'Soberana' onion during the growing cycle.

The nutrients extracted by 'Soberana' $\left(\mathrm{kg} \mathrm{ha}^{-1}\right)$ at the end of the growing cycle are shown in Table 1. Some nutrients are returned to the soil by foliar decomposition, and some are removed in the bulbs (export). Quantifying the accumulation of nutrients in the harvested tissues (export) is thus important for evaluating their removal from the crop area.

For the yield of $72.2 \mathrm{t} \mathrm{ha}^{-1}$, nutrient extraction was in the order $\mathrm{K}>\mathrm{Ca}>\mathrm{N}>\mathrm{S}>\mathrm{P}>\mathrm{Mg}>\mathrm{Fe}>$ $\mathrm{Mn}>\mathrm{Cu}>\mathrm{Zn}>\mathrm{B}$. The export order was $\mathrm{K}>\mathrm{Ca}>$
$\mathrm{N}>\mathrm{S}>\mathrm{P}>\mathrm{Mg}>\mathrm{Fe}>\mathrm{B}>\mathrm{Zn}>\mathrm{Mn}>\mathrm{Cu}$. The order of macronutrient export was the same as the order of extraction, but the micronutrient orders differed (Table 1). B was the least extracted but the second most exported micronutrient. $\mathrm{Zn}$ was the third least exported micronutrient, surpassing only $\mathrm{Mn}$ and $\mathrm{Cu}$. Vidigal, Moreira and Pereira (2010) reported distinct orders between extraction and export for 'Alfa Tropical' of $\mathrm{K}>\mathrm{N}>\mathrm{Ca}>\mathrm{S}>\mathrm{P}>$ $\mathrm{Mg}>\mathrm{Fe}>\mathrm{Mn}>\mathrm{Cu}>\mathrm{Zn}$ (extraction) and $\mathrm{K}>\mathrm{N}>$ $\mathrm{Ca}>\mathrm{P}>\mathrm{S}>\mathrm{Mg}>\mathrm{Mn}>\mathrm{Zn}>\mathrm{Fe}>\mathrm{Cu}$ (export).

Table 1. Nutrient extraction by plants, export in bulbs, and percentage of the export as a function of extraction (E/E) for the 'Soberana' onion at the end of the growing cycle (148 DAS).

\begin{tabular}{|c|c|c|c|c|c|c|c|c|c|c|c|}
\hline & $\mathrm{N}$ & $\mathrm{P}$ & $\mathrm{K}$ & $\mathrm{Ca}$ & $\mathrm{Mg}$ & $\mathrm{S}$ & $\mathrm{B}$ & $\mathrm{Cu}$ & $\mathrm{Fe}$ & $\mathrm{Mn}$ & $\mathrm{Zn}$ \\
\hline & \multicolumn{11}{|c|}{ - } \\
\hline Extraction & 102.0 & 24.4 & 230.5 & 120.8 & 18.0 & 43.6 & 0.27 & 0.30 & 0.72 & 0.46 & 0.29 \\
\hline Export & 44.6 & 13.4 & 94.6 & 46.7 & 7.9 & 18.9 & 0.14 & 0.02 & 0.25 & 0.07 & 0.10 \\
\hline \multicolumn{12}{|c|}{ 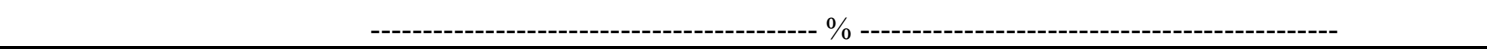 } \\
\hline $\mathrm{E} / \mathrm{E}$ & 44 & 55 & 41 & 39 & 44 & 43 & 50 & 7 & 35 & 15 & 35 \\
\hline
\end{tabular}


The recommended basal mineral fertilization for onion crops in São Paulo (SP) state, Brazil is 30 $\mathrm{kg} \mathrm{N} \mathrm{ha}{ }^{-1}, 90-300 \mathrm{~kg} \mathrm{P}_{2} \mathrm{O}_{5} \mathrm{ha}^{-1}, 60-150 \mathrm{~kg} \mathrm{~K}_{2} \mathrm{O} \mathrm{ha}^{-1}$, 0-2 $\mathrm{kg} \mathrm{B} \mathrm{ha}^{-1}, 0-4 \mathrm{~kg} \mathrm{Cu} \mathrm{ha}{ }^{-1}$, and 0-5 $\mathrm{kg} \mathrm{Zn} \mathrm{ha}^{-1}$. The recommended side dressing is $30-60 \mathrm{~kg} \mathrm{~N}^{-1}$ and 30-60 $\mathrm{kg} \mathrm{K}_{2} \mathrm{O} \mathrm{ha}^{-1}$ (TRANI; RAIJ, 1997). The total amounts of basal fertilization plus side dressing for $\mathrm{N}$ and $\mathrm{K}_{2} \mathrm{O}$ were thus 90 and $210 \mathrm{~kg} \mathrm{ha}^{-1}$, respectively. Extractions of $\mathrm{N}, \mathrm{P}_{2} \mathrm{O}_{5}, \mathrm{~K}_{2} \mathrm{O}, \mathrm{B}, \mathrm{Cu}$, and $\mathrm{Zn}$ in our study were 102.0, 55.9, 276.6, 0.27, 0.30 , and $0.29 \mathrm{~kg} \mathrm{ha}^{-1}$, respectively, for a yield far above $\left(72 \mathrm{tha}^{-1}\right)$ the average yield in SP $\left(37 \mathrm{tha}^{-1}\right)$, which may help the refinement of the fertilization recommendations for more productive genotypes.

Applying 33 and $71 \%$ of the total $\mathrm{N}$ and $\mathrm{K}_{2} \mathrm{O}$ as basal fertilization and 67 and $29 \%$ as side dressings, respectively, is recommended (TRANI; RAIJ, 1997), but $\mathrm{N}$ extraction by 60 DAS for 'Soberana' was approximately $12 \%$ of the total. The same extraction percentage was verified for $\mathrm{P}$ and $\mathrm{K}$ at 71 and 69 DAS, respectively. The recommended amounts of $\mathrm{N}, \mathrm{P}_{2} \mathrm{O}_{5}$, and $\mathrm{K}_{2} \mathrm{O}$ in the basal fertilization are thus much higher than needed by 'Soberana' until approximately midway through the growing cycle. It is also worth noting that the macronutrient requirement for 'Soberana' was highest between 61 and 148 DAS, and micronutrient requirement was highest between 70 and 148 DAS, which corresponded to 59 and $53 \%$ of the total for the growing cycle.

Side dressings of $\mathrm{N}$ and $\mathrm{K}_{2} \mathrm{O}$ are recommended at 20-30 and 45-55 days after transplanting (TRANI; RAIJ, 1997). Seedling formation requires 40 days, so these values would be equivalent to 60-70 and 85-95 DAS. The dates recommended for SP were therefore near the peaks of $\mathrm{N}$ and $\mathrm{K}$ demand for 'Soberana' that occurred at 98 and 107 DAS, respectively. Our results can help to customize the times of fertilizer application to the source and fertilization system.

\section{CONCLUSION}

Plant growth was slow at the beginning of the growing cycle and then accelerated after 81 DAS. The order of nutrient accumulation was $\left(\mathrm{g}_{\text {plant }}{ }^{-1}\right) \mathrm{K}$ $(0.72)>\mathrm{Ca}(0.38)>\mathrm{N}(0.32)>\mathrm{S}(0.14)>\mathrm{P}(0.08)>$ $\mathrm{Mg}(0.06)$ and $\left(\mathrm{mg} \mathrm{plant}^{-1}\right) \mathrm{Fe}(2.26)>\mathrm{Mn}(1.43)>$ $\mathrm{Cu}(0.93)>\mathrm{Zn}(0.91)>\mathrm{B}(0.85)$. The order of nutrient export was $\left(\mathrm{kg} \mathrm{ha}^{-1}\right) \mathrm{K}(94.6)>\mathrm{Ca}(46.7)>$ $\mathrm{N}(44.6)>\mathrm{S}(18.9)>\mathrm{P}(13.4)>\mathrm{Mg}(7.9)>\mathrm{Fe}(0.25)$ $>\mathrm{B}(0.14)>\mathrm{Zn}(0.10)>\mathrm{Mn}(0.07)>\mathrm{Cu}(0.02)$. The demand for macronutrients was highest between 61 and 148 DAS, and the demand for micronutrients was highest between 70 and 148 DAS.

\section{ACKNOWLEDGEMENTS}

The authors thank the Coordination for Improvement of Higher Education Personnel (CAPES) program for the Master's scholarship awarded to the first author and thank Agristar do Brasil Ltda.

\section{REFERENCES}

AGRISTAR. Topseed Premium Tecnologia em Sementes. Disponível em: <http://agristar.com.br/ topseed-premium/cebola-hibrida/aquarius-f1/2679>. Acesso em: 19 out. 2015.

AGUIAR NETO, P. Crescimento e acúmulo de nutrientes em cebola, melão e melancia nos estados do Rio Grande do Norte e Pernambuco. 2013. 205 f. Tese (Doutorado em Fitotecnia: Área de Concentração em Agricultura Tropical) Universidade Federal Rural do Semiárido, Mossoró, 2013.

AGUIAR NETO, P. et al. Crescimento e acúmulo de macronutrientes na cultura da cebola em Baraúna (RN) e Petrolina (PE). Revista Brasileira de Engenharia Agrícola e Ambiental, Campina Grande, v. 18, n. 4, p. 370-380, 2014.

BREWSTER, J. L. Onions and other vegetable alliums. Wallinford - UK: CAB International, 1994. $236 \mathrm{p}$.

COSTA, N. D. et al. Cultivares de cebola. Informe Agropecuário, Belo Horizonte, v. 23, n. 218, p. 2027, 2002.

EPSTEIN, E.; BLOOM, A. J. Nutrição mineral de plantas: princípios e perspectivas. 2. ed. Londrina, PR: Planta, 2006. 387 p.

FACTOR, T. L. et al. Correção do solo e adubação. In: NICK, C.; BORÉM, A. (Eds.). Cebola do plantio a colheita. 1. ed. Lavras, UFV, 2018. v. 1, cap.4, p. 58-77.

FERNANDES, A. M..; SORATTO, R. P.; SILVA, B. L. Extração e exportação de nutrientes em cultivares de batata: I - Macronutrientes. Revista Brasileira de Ciência do Solo, Viçosa, v. 35, n. 2, p. 2039-2056, 2011.

FURLANI, P. R.; PURQUERIO, L. F. V. Avanços e desafios na nutrição de hortaliças. In: MELLO PRADO, R. et al. (Eds.). Nutrição de plantas: diagnose foliar em hortaliças. Jaboticabal, SP: FCAV, 2010. cap. 3, p. 45-62.

HAAG, H. P.; MINAMI, K. Nutrição mineral de hortaliças. Campinas, SP: Fundação Cargil, 1988. $538 \mathrm{p}$. 
INSTITUTO BRASILEIRO DE GEOGRAFIA E ESTATÍSTICA - IBGE. Levantamento sistemático da produção agrícola [internet]. Instituto Brasileiro de Geografia e Estatística. 2016. Disponível em: <http://www.ibge.gov.br/home/ estatistica/indicadores/agropecuaria/lspa/ defaulttab.shtm>. Acesso em 18 mar. 2017.

JAGGI, R. C.; DIXIT, S. P. Onion (Allium cepa L.) responses to sulphur in representative vegetable growing soils of Kangra Valley of Himachal Pardesh. Indian Journal of Agricultural Sciences, New Delhi, v. 69, n. 4, p. 289-291, 1999.

KURTZ, C.; ERNANI, P. R. Produtividade de cebola influenciada pela aplicação de micronutrientes. Revista Brasileira de Ciência do Solo, Viçosa, v. 34, n. 1, p. 133-142, 2010.

KURTZ, C. et al. Crescimento e absorção de nutrientes pela cultivar de cebola Bola Precoce. Horticultura Brasileira, Brasília, v. 34, n. 2, p. 279288, 2016.

MALAVOLTA, E.; VITTI, G. C.; OLIVEIRA, S. A. Avaliação do estado nutricional das plantas: princípios e aplicações. 2. ed. Piracicaba, SP: POTAFOS, 1997. 319 p.

MORAES, C. C. et al. Fenologia e acumulação de nutrientes por cebola de dias curtos em semeadura direta. Revista de Ciências Agrárias, Lisboa, v. 39, n. 2, p. 281-290, 2016.

NASREEN, S.; HAQ, S. M. I.; HOSSAIN, M. A. Sulphur Effects on Growth Responses and Yield of Onion. Asian Journal of Plant Sciences, Islamabad, v. 2 , n. 12 , p. 897-902, 2003.

PÔRTO, D. R. Q. et al. Acúmulo de macronutrientes pela cultivar de cebola 'Optima' estabelecida por semeadura direta. Horticultura Brasileira, Brasília, v. 24, n. 4, p. 470-475, 2006.

PÔRTO, D. R. Q. et al. Acúmulo de macronutrientes pela cultivar de cebola 'Superex' estabelecida por semeadura direta. Ciência Rural, Santa Maria, v. 37, n. 4, p. 949-955, 2007.

PURQUERIO, L. F. V. Evolução histórica das tecnologias e insumos para a sustentabilidade na olericultura. Horticultura Brasileira, Brasília, v. 28, n. 2, p. 77-84, 2010.

PURQUERIO, L. F. V.; SANTOS, F. F. B.; FACTOR, T. L. Nutrient Uptake by Tomatoes 'Dominador' 'Serato' Grown in São Paulo State, Brazil. Acta Horticulturae, Brisbane, v. 1123, s/n., p. 35-40, 2016.
THOMAZELLI, L. F. et al. Nutrição da cultura da cebola para a produção de sementes. Florianópolis: Epagri, 2000. 40 p. (Boletim Técnico, 110).

TRANI, P. E.; RAIJ, B. van. Hortaliças. In: RAIJ, B. VAN. et al. (Eds.). Recomendações de adubação e calagem para o Estado de São Paulo. 2. ed. Campinas, SP: IAC, 1997. cap. 18, p. 157-185.

VENEGAS, J. G.; HARRIS, R. S.; SIMON, B. A. A comprehensive equation for the pulmonary pressurevolume curve. Journal of Applied Physiology, Rockville, v. 84, n. 1, p. 389-395, 1998.

VIDIGAL, S. M. et al. Crescimento e acúmulo de macro e micronutrientes pela melancia em solo arenoso. Ceres, Viçosa, v. 56, n. 1, p. 112-118, 2009.

VIDIGAL, S. M.; MOREIRA, M. A.; PEREIRA, P. R. G. Crescimento e absorção de nutrientes pela planta cebola cultivada no verão por semeadura direta e por transplantio de mudas. Bioscience Journal, Uberlândia, v. 26, n. 1, p. 59-70, 2010. 